\title{
THE RELATIONSHIP BETWEEN ORGANIZATIONAL CULTURE AND KNOWLEDGE SHARING: KIRKLARELI SAMPLE OF MANUFACTURING SECTOR ${ }^{(*)}$
}

\author{
Seda AKIN GÜRDAL ${ }^{1}$ ilknur KUMKALE \\ ${ }^{1}$ Kırklareli University Pınarhisar Vocational School of Higher Education \\ ${ }^{2}$ Trakya University Faculty of Economics and Administrative Sciences
}

\begin{abstract}
Today, knowledge is a very important resource for business organizations. As well as supporting business organizations, knowledge has become one of the most important components of all products and services. Knowledge needs to go through knowledge management processes in order to provide organizations benefits. Knowledge sharing, which is one of the knowledge management processes, brings organization in success. In terms of influencing behaviours, culture has a great importance on organizations as it has on societies. Organizatinnal culture is considered as an important factor which incluences the success of knowledge sharing. The aim of this study is to determine the organizational culture which is prevailing in organizations and to present the differences between the types of organizational culture and knowledge sharing. In the study, firstly organizational culture and its types, knowledge, knowledge culture, knowledge management and knowledge sharing were examined and in the application section, 378 questionaires were obtained from 12 organizations which are in service in manufacturing sector in Kurklareli Central district. The study is based on Cameron and Quinn's "Competitive Values Model". Knowledge sharing was examined as the type of knowledge sharing and the aspects of knowledge sharing. The type of knowledge sharing has been tackled as tacit and explicit knowledge and the aspects of knowledge sharing have been tackled as reward, being mutual, self-sufficiency, liking helping the others and respectability. In the scope of the data gathered, the hypotheses of the study have been tested and the findings have been included.
\end{abstract}

Key Words: Knowledge, Knowledge Sharing, Organizational Culture

\section{Introduction}

The importance of knowledge concept for business organizations increased more towards the end of 20th century as the economical changes in societies had influenced business organizations to a considerable extent. In agricultural society natural resources, in industrial society monetary fund, and in information society the source of power became knowledge. Knowledge had existed in every period of time, however, its meaning changed. In industrial society knowledge had helped the amount of production to increase

(*) This article has been prepared by extending the academic paper which was composed from a postgraduate thesis called "A Research Concerning theRelationship of Organizational Culture and Knowledge Sharing” and presented in "13th National Congress of Business Administration." 
and in information society it became a means that enabled adaptability to the environment (Kurt,2005:253-254). Along with the information society, by managing the knowledge, business organizations understood that they could create change and they could turn this into a competitive advantage (Erdil and Kitapçı, 2009:114).

The reason why the importance of knowledge had increased for business organizations is that it was taken to be considered as a"strategic resource". Knowledge as a strategic resource creates added value to goods and services (Kurt, 2005:250).

Knowledge became the production factor of all the goods and services which were produced, sold and purchased (Stewart, 1997:13). As well as supporting business organizations, knowledge and the relevant concepts became one of the components of all products and services (Davenport and Prusak,2000:36). Knowledge can provide sustainable advantage for business organizations. A company which is rich in terms of knowledge and which knows how to manage knowledge will have reached a new level of quality, creativity or productivity until it is realised (Davenport and Prusak, 2000:41). The fact that knowledge had become an important resource resulted in the fact that it is necessary to be managed. Today knowledge sharing, which is one of the knowledge management processes, is considered to be an important factor for business organizations to gain success. The success of knowledge management is related to the ability of organization to produce new knowledge and to transfer or share its present knowledge. The knowledge which remains in individuals' minds, folders, computer harddisks and which is not shared have no importance for organizations. Even one of the staff asking the other about how to do the work points out to knowledge sharing (Akgün, Keskin and Günsel, 2009:190). Knowledge sharing is described as the process realised by the staff to share the knowledge related to the organization with the other staff (Bartol ve Srivastava, 2002: 65). The significant point about knowledge sharing is to create an available backdrop and culture in the organization for knowledge sharing. When an evaluation is carried out concerning the infrastructure of knowledge management, the percentage of technology is $20 \%$, the percentage of organizational structure is $30 \%$ and the percentage of organizational culture is 50\% (Barutçugil,2000: 80). As well as being a factor that enables the organization to coexist and to be distinguished from the others, in terms of knowledge sharing, culture also has the power to influence knowledge sharing of the staff positively or negatively. Even if you have the best technology for knowledge sharing, as long as the people do not want to share, the knowledge wil not be shared. It has been pointed out that the most significant factor for knowledge sharing is the existence of a culture that supports knowledge sharing. It is important to lead the staff to a state that they can share their experiences and preconceived opinions (Celep and Çetin, 2003: 95-96). The concepts which will determine that the knowledge is shared successfully such as values, norms and behaviours are also the factors that will determine organizational culture (Davenport and Prusak,2000:141). In the cultures that are not based on respect and trust and that are predominated by fear, employees do not share knowledge. They regard knowledge as power and they keep the knowledge as an indispensible value 
for their futures (Yeniçeri and Demirel, 2007: 11). Recently the idea that level of competition will increase when knowledge sharing is encouraged in organization has also enhanced the interest in knowledge sharing.

Although the issues such as organizational culture and knowledge sharing are important for organizations, the subject has not been examined a lot in the literature. Therefore, it is considered that the findings of this study will be referable for the future studies.

In the scope of this study, the aim is to determine the organizational culture that is prevailing in business organizations and to present the differences between the types of organizational culture and knowledge sharing. The study, which was applied in manufacturing sector, was especially applied in lots of organizations in order to have the chance to evaluate knowledge sharing in various types of organizational culture.

\section{Organizational Culture}

If we define culture as the lifestyle of a society, then organizational culture can be defined as the management style of an organization. Organizational culture is composed of features and values, beliefs, norms and symbols that help the organization to be distinguished from the others (Doğan, 2007: 102). The culture of every organization is unique. There is no organization which does not have an organizational culture even if they are newly founded. Organizations are social structures that produce goods and services. In this production process, some traditions, beliefs, values, stories and symbols come to the forefront while working. And these are the elements that represent organizational culture.
(Erkmen, 2010: 31). Pettigrew who introduced the organizational culture concept to literature defined it as "the meanings systems which are shared in any place, time and group", Peter and Waterman defined it as "the sets of shared values", Deal and Kennedy defined it as " a manner improver, the way everything in the organization is done", Simircich defined it as "the shared perceptions, meanings, beliefs and values of organization members" (Şişman, 2007: 81). The concept was introduced to American literature by Pettigrew with his article "On Studying Organizational Culture" that he had written for Admistrative Science Quartley journal in 1979. Deal and Kennedy's book "Corporate Culture" was published in1982 and Mc Kinsey, Peters and Waterman's book "In Search of Excellence" was published in the same year. A large literature had been formed in Europe since then (Hofstede, 1990: 286), and apart from these together with Pascale and Athos's book "The Art of Japanese Management" during that period the concept of organizational culture had become more popular (Şişman, 2007: 73). In 1980s there was a big financial downfall in Western societies. Besides, Japan had started to become a leader in international market. During the period the fact that American administrative mentality, whose supremacy was widely accepted, could not respond to the developments in 1980s caused it to be questioned. Academicians, who were in search for new solutions, had come to the conclusion that the answer to the problem to improve productivity in organizations was in organizational culture studies (Yağmurlu, 2006: 718).

\subsection{Cameron and Quinn "Competing Values} Framework" 
Cameron and Quinn had developed an organizational culture framework called "Competing Values" in which, by gathering the studies of some researchers, they present the relationship between culture and organizational activity (Goodman, 2001: 60). Researchers had stated that as well as being financially successful, the strategy is effective for the payment that was expected by the members of the organization and suitable personnel management. They explained that to find and apply more successful and effective strategies depended on the desires and the capacity of creativity of the staff and it was stated that the emergence of these successful strategies depended on the capacity of creativity of the staff. In the recent studies it has been attempted to measure the relationship between organizational culture and organizational success and Competing Values Framework, which examines the relationship between organizational success and organizational culture, has been developed (Eren,2010: 147). Competing values approach reveals the available or desired cultural profile of an organization. In this respect, it is a kind of guideline for leaders, managers and mentors who aim at cultural change (Hooijberg ve Petrock, 1993: 29). Cameron and Quinn defined organizational culture in four types. These are: clan, hierarchy, market and adhocracy cultures In common values under each type of culture, prevailing qualifications are leadership style, coalescence, and strategic importance (Eren,2010: 148).

\subsubsection{Clan Culture}

This culture is a backdrop to improve team work and human resources (Cameron ve Quinn, 2006: 41). Clan culture is a culture in which people make a self sacrifice and add something from themselves (Erdem, Adigüzel ve Kaya, 2010: 79). In this type of culture, values such as the working style of organization, team work, family awareness, protecting the traditions, improving human resources are much more superior than marketshare and financial earnings (Eren, 2010: 14). In Clan culture the leader is called the mentor, facilitator and acts as a parent. The strategical point is the human resources. Loyalty and traditions interconnect the individuals. While the success is being described, it is based on the sensitivity and interest towards customers (Murat ve Açıköz, 2007: 5-7).

\subsubsection{Adhocracy Culture}

Adhocracy culture is a dynamic culture which attaches importance to enterpreneurship. The leader in this type of culture is enterprising and innovative. The staff are open to enterprise and innovations, too. And this strengthens the interpersonal relationships. Its strategical focus is to increase economically and find new resources (Murat and Aç1kgöz, 2007: 5). Adhocracy culture encourages people to creativity (Cameron and Quinn, 2006: 43). In this type of culture organizational status and positions are not important and the structure is flexible to the highest degree (Erdem, 2007: 66). It is a culture in which the staff do not avoid taking risks and are able to take initiative individually. While the success is being defined, it is important to become a leader in order to have the unique and new goods and services.

\subsubsection{Market Culture}

The major concern of the market culture is to finish and accomplish work. The leaders in this culture 
have productive and competitive roles. This type of organizational structures generally focuses on the factors in the external surroundings (Erdem et al., 2010: 79). The concept of "earning" is important to hold the organization together. Success is regarded as the market share and penetrating to the market. It plans to reach competitive activities and measurable targets and aims in the long term. In terms of the relationship among individuals, the essentiality is to accomplish the duties and the aims successfully (Murat and Açıkgöz,2007:7). In the market culture, individuals struggle for their own interests. The staff's contribution to the shared interest is measured and the staff who are contributing and not contributing are evaluated accordingly (Erdem, 2007: 66).

\subsubsection{Hierarchy Culture}

Hierarchy Culture is also called bureaucracy culture. The connection that holds the staff together is the formal rules and policies. The strategical focuses of this type of organizations are stability and consistency. The leaders praise themselves on being a coordinator and manager. The staff consult to the procedures on the management of their activities. The target is an organizational structure which works like clockwork (Murat and Açıkgöz, 2007:5-7). The individuals are not expected to add something from themselves while working. According to this type of organizational culture, it is assumed that the more experienced, centralized and formal an organization is the better (Erdem et al., 2010: 80). Religious, military and formal organizations, big natural resource enterprises and developed fast food businesses can be given as an example to this type of organizational culture (Şişman, 2007: 145).

\section{Knowledge and Knowledge Management}

Knowledge and management; these are two concepts which are difficult to piece together. Knowledge is a personal concept related to knowing and comprehending. The concept of management, on the other hand, describes the organizational processes that require team work for the common purposes. Owing to the fact that knowledge is a resource which has a critical significance for businesses that helps them to outclass the others in the market, Knowledge management has become so important that it cannot be left up to chance (Barutçugil, 2000: 55).

\subsection{Knowledge and Types of Knowledge}

Knowledge is a concept that is difficult to define. According to Alavi and Leidner, knowledge is the internalised information that an individual has concerning the events, procedures, concepts, ideas, observations and judgments (Alavi and Leidner, 2001: 109). It is observed that the concept of knowledge has been classified in the literature according to certain criteria in order to understand its meaning better.

Polanyi had presented knowledge classification in his book "The Tacit Dimension" in 1967, and in 1994 Nonaka, by depending upon Polanyi's study, procured acceptance on explicit and tacit knowledge classification (Alavi ve Leinder, 2001: 110). Explicit knowledge is the databases composed of words, numbers, data and formulas and information that can be transferred and disseminated (Beijerse, 2000: 3). Explicit knowledge can also be coded and brought out with a systematic and formal language (Tiwana, 2003: 87). Explicit knowledge, whose correctness 
is acknowledged by everybody, is easilly being shared via information technologies. Due to the fact that explicit knowledge is comprehensible for everybody, it can easilly be spread within the organization. Books, brochures, databases, reports are examples to this type of knowledge (Durna and Demirel, 2008: 144). Tacit knowledge is a type of knowledge which is in people's minds so, which is difficult to transfer and spread, it is difficult to describe and it is relativistic (Odabaş, 2005: 105). Tacit knowledge is related to people's beliefs, values, feelings and experiences (Zaim, 2005: 75). Individuals can define and express less than what they know because they do not need it. Tacit knowledge can be stated and recorded individually (Durna and Demirel, 2008: 142). This type of knowledge is formed as a result of ability and human relations (Aktan and Vural, 2005: 7).

\subsection{Knowledge Management}

Human beings have wanted to use knowledge in order to benefit from it since they had existed (Bayram, 2010: 67). Beijerse defined knowledge management as "to realise the aims of the organization by making the knowledge factor productive" (Beijerse, 2000: 165). O'Dell defined knowledge management as an approach of obtaining, understanding, and using knowledge in order to create a value, Laudon and Laudon defined it as a systematic process which takes place in order to increase the level of knowledge in organization and to manage knowledge (Uzun, 2007: 20). Knowledge management, even if not in today's meaning, is a process which has been known and practised for centuries. For centuries, family business owners have transferred their commercial skills to their children, Mentors have carefully taught their artisanship to their aprentice, and workers have exchanged their ideas and knowledge about their jobs. It was not until 1990s that senior managers have started to mention about knowledge management (Yeniçeri and İnce, 2005: 73). Since 1990s knowledge management have been accepted as a management process. In today's successful organizations, knowledge management is defined as the process of creating and using of organizations' own institutional and collective knowledge. Knowledge management can be applied in all organizations ranging from private sectors to government sectors. However it cannot be expected that knowledge management goes through the same processes in all organizations. Even if the stages such as acquiring knowledge (supplying and improving knowledge), internalising knowledge (storing and preserving), sharing knowledge (transfering and spreading) and using knowledge (applying and evaluating) are not known by name in organizations they are actively existing (Keskin and Kalkan, 2005: 183).

\section{The Concept of Knowledge Sharing}

Knowledge sharing is an important stage of knowledge management. Knowledge is the most important means of creating values and its value increases as it is shared. This feature caused people to adopt "Knowledge sharing is power" approach (Gurteen, 1999: 3).Knowledge sharing is described as the process in which the staff members share the knowledge related to the organization with the other staff members (Bartol and Srivastava, 2002: 65). Today, knowledge sharing is regarded as an important factor for organizations in order to gain success. When the staff members share their knowledge with the other members, they 
can gain the competitive advantage that they need. The fact that the organizations have the ability of knowledge sharing among the staff brings success to the organization (Matzler, 2008: 301). The contribution of knowledge sharing to the organization's performance takes place in the literature a lot (Szulanski, 2000: 12). In a research about knowledge sharing which was carried out by Toyota, it was observed that as knowledge sharing increased, organizational performance increased,too (Demirel, 2007: 103). In the organization, every staff member in every level is expected to be open to knowledge sharing. Drucker defines the priority of the organizations which want to be successful as "to be able to manage the intellegence and the character of every staff member in all levels of the organization to be able to create and share knowledge. As well as the technological obstacles that prevent knowledge to be shared, behavioural tendencies of the organization's staff, control, and their reactions to motivation systems are also regarded as obstacles (Karadal and Özçınar, 2003: 499). As well as the technological substructure in the organization, human factors are also in the foreground concerning the knowledge sharing (Yeniçeri and İnce, 2005: 124). Human factor must not be neglected concerning the issue of knowledge sharing. Knowledge sharing can be realised interpersonally in organizations, it can be realised among organizations and customers, as well (Yeniçeri and Demirel, 2007: 10). The contributory factors to knowledge sharing have been discussed as individual factors, organizational factors and factors related to knowledge in lots of the studies. The knowledge sharing factors related to knowledge are about whether it is tacit or explicit knowledge. Sharing of tacit knowledge and explicit knowledge is different from each other and Explicit knowledge sharing is easier than tacit knowledge sharing (Ipe, 2003: 344). Among the factors related to organization, especially the culture factor has a great contribution to knowledge sharing. As the organizational culture is important in every process of knowledge management, it is important in knowledge sharing, as well. Culture is a factor which holds the organization together and helps it to be distinguished from the others. Culture has the power to influence the staff's knowledge sharing positively or negatively. The individual's character is also important in terms of knowledge sharing. The motivation factor, which influences knowledge sharing among individuals, is divided into two parts as internal and external motivation. Internal factors, the belief that the knowledge is power, create a entanglement about knowledge sharing. The interactions with the receiver and rewards are regarded as external factors. The assimilative capacity is defined as the ability of using new knowledge in the organization by appreciating and internalising it (Akgün et al., 2009: 190). Cultural factors that block knowledge sharing are named as frictions by Davenport and Prusak. Frictions are thought to decrease knowledge sharing or put it completely away. Lack of trust, different cultures, not being able to find time and place to negotiate, the fact that the ones who have the knowledge hold the whip hand, the receivers' lack of assimilative capacity and grouping are considered to be knowledge sharing obstacles. Interacting face to face, creating time and place for knowledge sharing, rewarding knowledge sharing, encouraging, not having a monopoly on knowledge and tolerating the mistakes done 
are the possible solutions that are listed for these obstacles. (Davenport and Prusak, 2000).

\subsection{Dimensions of Knowledge Sharing}

The issues related to knowledge sharing in organizations, however, special methods of measurement in the literature are limited. The knowledge sharing scale which was developed by Kankanhalli, Tan and Wei is discussed in five dimensions. This scale was used in the application part of this study. Therefore it is considered necessary to explain these knowledge sharing dimensions of this scale. The dimensions of the scale are as follows:

Organizational Reward: When the encouragement is more than the cost of the knowledge that is shared, knowledge sharing is thought to be rewarded (Hung and Chuang, 2011: 5). Organizational rewards such as payment, premium, bonus, labor-job protection and promotion in the career increase knowledge sharing (Kankanhalli, Tan and Wei, 2005: 120).

Respectability: Knowledge enables the staff in the workplace to be regarded as precious. It provides the staff with respectability and a better image (Kankanhalli et al., 2005: 120). Knowledge sharing is important to create dignity in the organization (Hung and Chuang, 2011: 6).

Being Mutual: When the staff members share their knowledge, they tend to expect a response. Mutual advantage is important in knowledge sharing. According to the previous studies, the people who had shared knowledge believed that it needed a compensation in return. Being mutual has a positive relationship with knowledge sharing (Kankanhalli et al., 2005: 121-122).
Self-Efficacy: Especially sharing the useful knowledge for the organization is also an opportunity for the staff to develop their self-efficacy (Hung and Chuang, 2011: 5). It is related to the perceptions of the individial for his/her own skills. When the people share their useful experiences with the organization their self-esteem and self-efficacy increase. This belief can enable the person to motivate himself or herself (Kankanhalli et al., 2005: 122).

Liking to Help to the Others: This benefit derived from the concept of altruism. People can make a sacrifice willingly without expecting something in return. People can be motivated to help the others (Kankanhalli et al., 2005: 122). People can enjoy and feel satisfied when they help the others.

\section{The Relationship between Organizational Culture and Knowledge Sharing}

Peters and Waterman draw attention to the fact that organizational culture is an important factor for the organizational success in their book "In Search of Excellence" which is one of the works written in the field of organizational culture that was introduced to the literature in 1980s. Organizational culture had become a much more popular subject especially after being associated with organizational assets (Erkmen, 2010: 1). Organizational culture helps the organization to be distinguished from the other organizations. Every state of affairs in the organization is shaped by the organizational culture. Organizational culture can support the issues concerning the change, and it can prevent them, as well. And as well as being supportive to the applications of knowledge management, organizational culture sometimes can 
be interceptive. In an international study carried out on 500 firms, it has been stated by $80 \%$ of the attending firms that the biggest obstacle to knowledge management applications is "the existing organizational culture". Cultural factors play a key role on the success of knowledge management processes (Uzun, 2007: 90). Delong and Fahey has emphasized the importance that the organizational culture attaches to knowledge and stated how it influences knowledge management. Concerning the knowledge, organizational culture is effective on behaviours in four ways. These are; (Delong and Fahey, 2000: 116-123).

- Culture shapes the assumptions about which knowledge is important.

- Culture acts as an agent in the relationship among the levels of knowledge.

- Culture creates a connection for social interaction.

- Culture creates the new knowledge and enables people to adapt it.

Culture is also effective on knowledge sharing and the issue of knowledge sharing is a matter of organizational culture further to that it is only the subject of knowledge management (Dinçmen, 2010: 209). The things that will determine the success of knowledge sharing are factors that will determine the organizational culture such as values, norms and behaviours (Davenport ve Prusak, 2000: 141). The staff who work in the fear-dominated organizations which do not depend on respect and trust do not share knowledge.. They regard the knowledge as power and keep knowledge as an indispensible value for their futuresd (Yeniçeri and Demirel, 2007: 11). Whereas, in Ruppel and Harrington's study in which they examined the influence of organizational culture on knowledge sharing via intranet, there is a positive relationship between clan cultures, in which cooperation is in the forefront, and intranet using, it was concluded that market cultures, in which rivalry is important, do not support knowledge sharing via intranet. (Ruppel and Harrington, 2001: 37-52). In Suppiah and Sandhu's study in which they examined the influence of organizational culture behaviours on the behaviour of tacit knowledge sharing, it is stated that the studies related to knowledge sharing and organizational culture are limited. Tacit knowledge sharing behaviour has been examined in terms of organizational communication, trust, mentorship and eagerness to share knowledge. In the study that has been carried out in 10 organizations, clan culture has a positive effect on tacit knowledge sharing. Market and hierarchy cultures, on the other hand, have a negative effect on tacit knowledge sharing. In the study, it has been determined that the most suitable organizational culture to share tacit knowledge is clan culture (Suppiah and Sandhu, 2010: 462-477).

\section{The Importance, the Purpose and the Met- hod of the Research}

This study has focused on organizational culture and knowledge sharing. The purpose of the study is to determine the organizational culture prevailing the business organization and to present knowledge sharing differences in various types of organizational culture. It is observed that in most of the studies on organizational culture, Competitive Values Approach is used. However, it is aimed to contribute to the subject of organizational culture and knowledge sharing whose inadequacy in the literature attract attention to 
be useful for the researchers in the future. In the study, survey method has been used to gather the data. Questionaire form consist of three scales as organizational culture, knowledge sharing types and knowledge sharing dimensions and demographical questions. The scales that has been used in the questionaire form are 5 likert-type sclaes. In the questionaire form there are 5 questions related to demographical information, 16 questions related to organizational culture, 7 questions related to knowledge sharing types and 21 questions related to knowledge sharing dimensions. In the study, clan, adhocracy, hierarchy and market cultures which was addressed in Cameron and Quinn's (1992) "Competitive Values Approach" organizational culture model have been used (Cameron ve Quinn,2006). Competitive Values Approach reveals the existing or desired cultural profile of an organization (Hooijberg and Petrock, 1993,29). In terms of knowledge sharing, the model that Xi Zhang had used (2011) in his study themed "Cultural Influences On Explicit and Implicit Knowledge Sharing Behaviour In Virtual Team" has been predicated as the base. The questions related to knowledge sharing dimensions and the questions related to explicit and tacit knowledge sharing have been adapted from Kankanhalli (Kankanhalli, Tan and Wei, 2000;Lee, 2001;Zhang,2011).

A pilot study was carried out to test the reliability of the questions after the questionaire form had been shaped. After the pilot study, it has been confirmed that the questionaire is suitable to apply. Manufacturing organizations in Kırklareli Central District that has more than 50 workers is the population of the research. According to the records of Social Security Institution in 2012 there are 17 manufacturing organizations in Kırklareli Central District and the population of the research is composed of 3006 employees. According to $\pm \% 5$ error level, When the population size is 3006 , then it is stated that the research sample size can be 341 (Altunışık, 2007,127). The subjects of the research are organizations that are active in textile, food, machinery, aluminium manufacturing and moulding sectors. In the study, stratified sampling method has been used. There are 17 organizations in Kurklareli Central District, however, 12 organizations have accepted to take part in the research. $15 \%$ of the employees of each 12 organization attending the research have been delivered a questionaire and 378 questionaires have been obtained.

\section{The Research Model}

The research model is illustrated in Figure 1 below and the research has been configured according to this. 
Figure 1. The Research Model

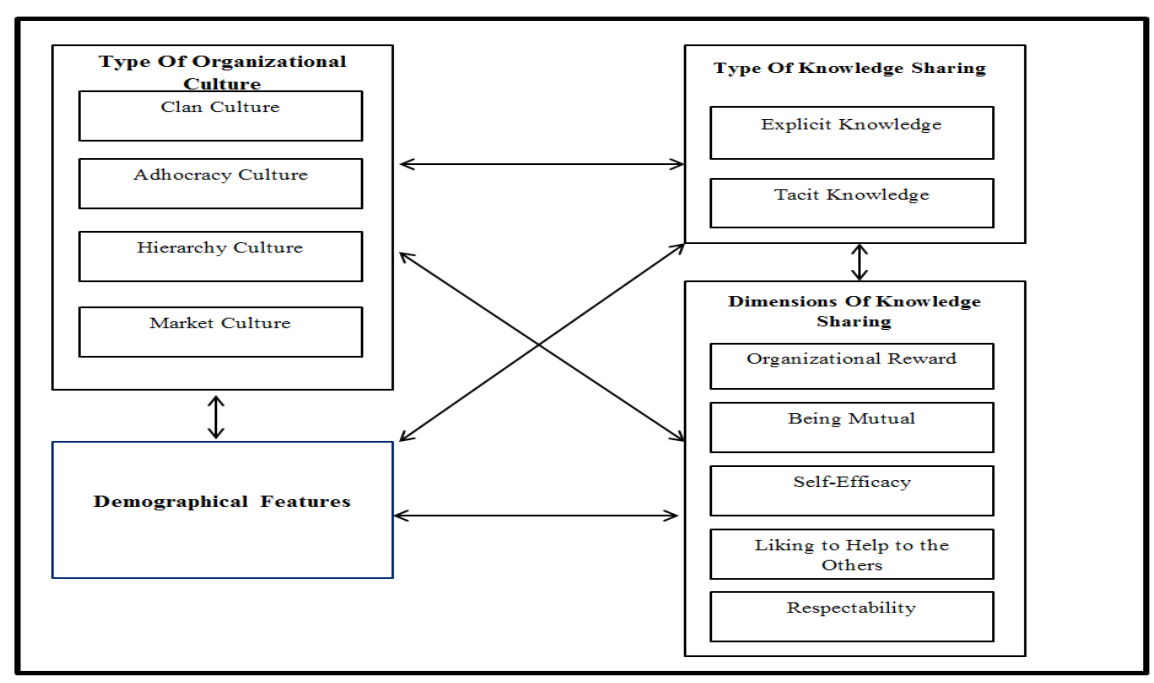

\section{The Hypotheses of the Research}

In the scope of the research, the hypotheses to be tested in terms of the types of organizational culture, explicit knowledge, tacit knowledge and knowledge sharing dimensions are as follow:

Hypothesis 1: The knowledge sharing types differ according to demographical features.

Hypothesis 2: The knowledge sharing dimensions differ according to demographical features.

Hypothesis 3: The knowledge sharing types differ according to organizational culture types.
Hypothesis 4: The knowledge sharing dimensions differ according to organizational culture types.

\section{Analyses of the Data}

While evaluating the data SPSS 17.0 software program was used. Factor analysis have been applied to analyse the reliability and the structural validity of the scales used in the research. While analyzing the data, frequency tables, mean values, independent samples $t$ test, analysis of variance have been applied.

The table related to the demographical features of the research participants is below. 
Table 1:Demographical Features

\begin{tabular}{|l|l|l|l|}
\hline Demographical Variable & Category & Number & Percentage \\
\hline Gender & Woman & 184 & 48.7 \\
& Man & 194 & 51.3 \\
\hline \multirow{5}{*}{ Age } & $18-25$ & 86 & 22.8 \\
& $26-35$ & 179 & 47.4 \\
& $36-45$ & 98 & 25.9 \\
& More than 46 years & 15 & 4.0 \\
\hline Educational Status & Primary school & 42 & 11.1 \\
& Secondary school & 124 & 32.8 \\
& Highschool & 151 & 39.9 \\
& Associate degree & 34 & 9.0 \\
& Bachelor's and Master's degree & 27 & 7.1 \\
\hline Working Time & Less than 1 year & 154 & 40.7 \\
& 1-5 years & 179 & 47.4 \\
& 6-10 years & 31 & 8.2 \\
& 11-15 years & 4 & 1.1 \\
& More than 16 years & 10 & 2.6 \\
\hline Job & Worker & 263 & 69.6 \\
& Officer & 67 & 17.7 \\
& Chief- Foreman & 31 & 8.2 \\
& Engineer & 9 & 2.4 \\
& Assistant Manager & 3 & 0.8 \\
& Manager & 5 & 1.3 \\
\hline
\end{tabular}

When the gender distribution of the research participants is examined in Table 1, It is seen that $48.7 \%$ of the participants are women and $51.3 \%$ are men. When the age distribution of the research participants is examined $22.8 \%$ are aged between $18-25,47.4 \%$ are aged between $26-35,25.9 \%$ are aged between $36-45,4.0 \%$ are 46 and above. $11.1 \%$ of the research participants are primary school graduates, $32.8 \%$ are secondary school graduates, 39.9\% are highschool graduates, $9.0 \%$ have aassociate degree, $7.1 \%$ have bachelor's and master's degree. When the distribution of the research participants is examined in terms of work time, $40.7 \%$ have worked for less than 1 year, $47.4 \%$ for $1-5$ years, $8.2 \%$ for $6-10$ years, $1.1 \%$ for $11-15$ years and $2.6 \%$ have worked for 16 years and more. When the distribution of the research participants is examined in terms of their jobs, $69.6 \%$ are workers, $17.7 \%$ are officers, $8.2 \%$ are chief and foremen, $2.4 \%$ are engineers, $0.8 \%$ are assistant managers and $1.3 \%$ are managers.

\subsection{Factor and Reliability Analysis}

The purpose of factor analysis is to facilitate to understand and interpret the relationships among many variables that are thought to be related and it is an analysing method which is used to potentially lower the number of variables into a basic form (Altunış1k, 2007, 222). The matters in the scales related to knowledge sharing have been put through factor analysis. It has been tried to get consistent factors less than the matters in the scales. Due to the fact that Cameron and Quinn's organizational culture scale was adapted in lots of studies, the factor analysis was not necessary for it. 
Table 2 : The Results of Factor and Reliability Analyses of the Scale of Knowledge Sharing Types

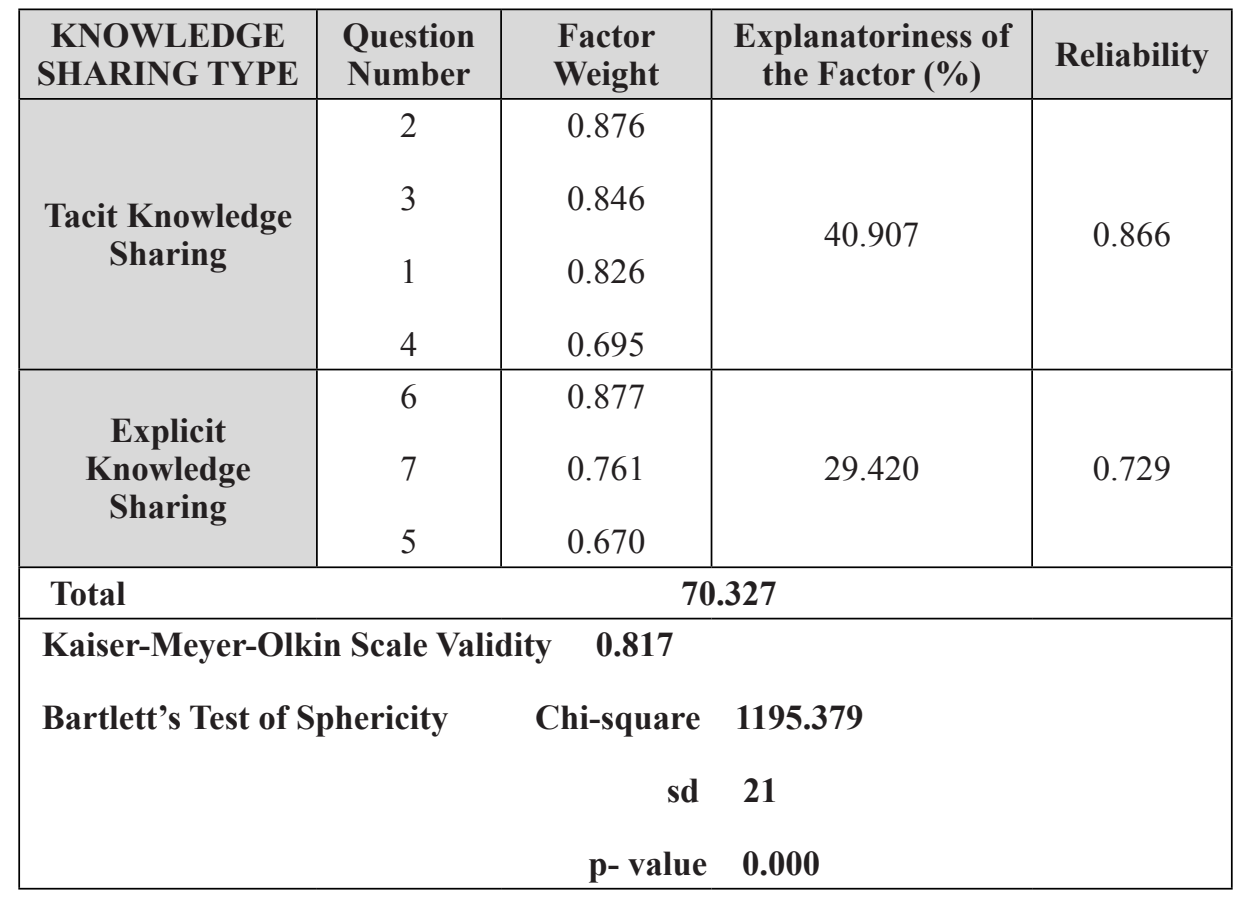

The result of factor analysis (Table: 2) for the scale of knowledge sharing type KMO coefficient is 0.817 and Barlett's Test value is 1195.379 $(\mathrm{p}<0.001)$ and a two-factor structure that interprets $70.32 \%$ of the total variance has been gained. As a result of factor analysis, tacit knowledge sharing factor $(40.907 \%)$ that interprets the variance is a formation of four matters. The matters in this factor is related to tacit knowledge sharing. Explicit knowledge sharing factor(29.430\%) is a formation of three matters. This scale, which was taken from Lee show different factoring in terms of tacit and explicit knowledge sharing. In the original scale, whereas the $4^{\text {th }}$ matter comes under explicit knowledge sharing, in the study, it is factoring under tacit knowledge sharing. In the scale of knowledge sharing type, reliabity analysis result of tacit knowledge sharing has been found as 0.866 and reliability analysis result of explicit knowledge sharing has been found as 0.729 . The result of tacit knowledge sharing is highly reliable and the result of explicit knowledge sharing is reliable. 
Table 3 : The Results of Factor and Reliability Analyses of the Scale of Knowledge Sharing Dimensions

\begin{tabular}{|c|c|c|c|c|}
\hline $\begin{array}{l}\text { KNOWLEDGE SHARING } \\
\text { DIMENSIONS }\end{array}$ & $\begin{array}{l}\text { Question } \\
\text { Number }\end{array}$ & $\begin{array}{l}\text { Factor } \\
\text { Weight }\end{array}$ & $\begin{array}{l}\text { Explanatoriness of the } \\
\text { Factor }(\%)\end{array}$ & Reliability \\
\hline \multirow{4}{*}{ Reward } & 9 & 0.862 & \multirow{4}{*}{17.313} & \multirow{4}{*}{0.900} \\
\hline & 10 & 0.842 & & \\
\hline & 8 & 0.763 & & \\
\hline & 11 & 0.706 & & \\
\hline \multirow{4}{*}{ Being Mutual } & 13 & 0.832 & \multirow{4}{*}{14.816} & \multirow{4}{*}{0.854} \\
\hline & 14 & 0.809 & & \\
\hline & 15 & 0.749 & & \\
\hline & 12 & 0.672 & & \\
\hline \multirow{4}{*}{ Self-Efficacy } & 18 & 0.752 & \multirow{4}{*}{14.308} & \multirow{4}{*}{0.747} \\
\hline & 17 & 0.727 & & \\
\hline & 19 & 0.681 & & \\
\hline & 16 & 0.561 & & \\
\hline \multirow{4}{*}{ Liking to Help the Others } & 21 & 0.851 & \multirow{4}{*}{13.829} & \multirow{4}{*}{0.869} \\
\hline & 22 & 0.776 & & \\
\hline & 20 & 0.766 & & \\
\hline & 23 & 0.623 & & \\
\hline \multirow{5}{*}{ Respectability } & 26 & 0.783 & \multirow{5}{*}{11.020} & \multirow{5}{*}{0.895} \\
\hline & 27 & 0.773 & & \\
\hline & 25 & 0.771 & & \\
\hline & 28 & 0.717 & & \\
\hline & 24 & 0.698 & & \\
\hline \multicolumn{4}{|c|}{71.286} & \\
\hline \multicolumn{5}{|c|}{ Kaiser-Meyer-Olkin Scale Validity $\quad \mathbf{0 . 9 1 0}$} \\
\hline \multirow[t]{3}{*}{ Bartlett's Test of Sphericity } & Chi-squar & \multicolumn{2}{|c|}{4960.737} & \\
\hline & & 210 & & \\
\hline & p- val & 0.000 & & \\
\hline
\end{tabular}

The factor analysis results related to knowledge sharing dimensions are shown in Table 3 Related to knowledge sharing dimensions, the reward factor interprets $17.313 \%$ of the total variance and consists of four matters. Being mutual factor interprets $14.816 \%$ of the total variance and consists of four matters. This factor is about taking something in return when the staff share knowledge. The self-efficacy factor interprets $14.308 \%$ of the total variance and consists of four matters. This matter is related to how the staff consider their knowledge efficiency. The liking to help the others factor interprets $13.829 \%$ of the total variance and consists of four matters. This matter describes the pleasure that the staff have when they help each other by sharing knowledge. Finally the respectability factor interprets $11.020 \%$ of the total variance and consists of five matters. Reliability analysis results of Knowledge sharing dimensions are respectively; reward dimension is 0.900 , being mutual dimension is 0.854 , self-efficacy dimension is 0.747 , liking to help the others dimension is 0.869 and respectability dimension is 0.895 . The result is that self-efficacy dimension is reliable and the others are highly reliable. 


\subsection{Descriptive Statistics}

Table 4: Prevailing Cultures of the Organizations Participating in the Research

\begin{tabular}{|c|c|c|c|c|c|c|c|c|c|c|c|}
\hline $\mathbf{1}$ & $\mathbf{2}$ & $\mathbf{3}$ & $\mathbf{4}$ & $\mathbf{5}$ & $\mathbf{6}$ & $\mathbf{7}$ & $\mathbf{8}$ & $\mathbf{9}$ & $\mathbf{1 0}$ & $\mathbf{1 1}$ & $\mathbf{1 2}$ \\
\hline Market & Adhocracy & Market & Market & Market & Market & Market & Clan & Hierarchy & Market & Hierarchy & Clan \\
\hline
\end{tabular}

As the average results of organizations participating in the research, the prevailing cultures are: The organizations $1,3,4,5,6,7$ and 10 are market cultures, in the organization 2, adhocracy culture is the prevailing culture. In the organizations 9 and 11 , hierarchy culture is the prevailing culture and in the organizations 8 and 12, clan culture is the prevailing culture. It is observed that in most of the organizations participating in the research, market culture is prevailing.

In the scope of the study, when the average values of explicit and tacit knowledge are examined, apart from the organizations 6 and 8, in all of the organizations tacit knowledge average value is higher than the explicit knowledge average value. When knowledge sharing dimensions in organizations are examined, the organization 10 has the highest average value in reward dimension, the organization 7 has the highest average value in being mutual dimension, the organization 10 has the highest average value in self-efficacy dimension, the organization 7 has the highest average value in liking to help the others dimension and the organization 6 has the highest average value in respectability dimension.

\subsection{Knowledge Sharing Types According to Organizational Culture Types and the Averages of Knowledge Sharing Dimensions}

In which culture the highest and the lowest average values of knowledge sharing type and knowledge sharing dimensions occur is in the table below.

Table 5: The Averages of Knowledge Sharing Types and Knowledge Sharing Dimensions According to Organizational Culture Types

\begin{tabular}{|l|c|c|c|c|c|c|c|}
\hline & $\begin{array}{c}\text { Explicit } \\
\text { Knowledge }\end{array}$ & $\begin{array}{c}\text { Tacit } \\
\text { Knowledge }\end{array}$ & Reward & $\begin{array}{c}\text { Being } \\
\text { Mutual }\end{array}$ & $\begin{array}{c}\text { Self- } \\
\text { efficacy }\end{array}$ & $\begin{array}{c}\text { Liking to } \\
\text { Help the } \\
\text { Others }\end{array}$ & Respectability \\
\hline Clan & 3.16 & 3.53 & 2.75 & 3.71 & 3.33 & 3.78 & 3.26 \\
\hline Adhocracy & 2.86 & 2.93 & 2.21 & 2.66 & 2.86 & 2.73 & 2.49 \\
\hline Market & 3.54 & 3.81 & 3.26 & 3.28 & 3.53 & 4.03 & 3.60 \\
\hline Hierarchy & 3.41 & 3.57 & 3.40 & 3.59 & 3.65 & 3.88 & 3.66 \\
\hline
\end{tabular}

In table 5, the highest averages of explicit and tacit knowledge sharing dimensions are in market culture and the lowest averages are in adhocracy culture. It is also seen that reward dimension has the highest average in hierarchy culture and the lowest in adhocracy culture. Being mutual dimension is the highest in clan culture and is the lowest in adhocracy culture. Self-efficacy dimension is the highest in hierarchy culture and is the lowest in adhocracy culture. Liking to help the others is the highest in market culture and is the lowest in adhocracy culture. And respectability 
dimension is the highest in hierarchy culture and is the lowest in adhocracy culture.

\subsection{Difference Analyses of Knowledge Sharing Types According to Demographical Features}

Normal distribution is the first hypothesis that is necessary to obtain in order to use parametric tests such as correlation, regression, $t$ test and one-way analysis of variance (Sipahi, 2010: 65). An interpretation about normal distribution can be done by looking at kolmogorov-smirnov value to examine the status of normal distribution. In our research, normal distribution, which is the initial condition of parametric tests, has been examined and and normal distribution condition has been fulfilled. It is necessary to pay attention to the fact that group variances in $\mathrm{t}$ test and one-way variance analysis, which are used to test the differences, are homogeneous. It is necessary that $p$ value of Levene test statistics is higher than 0.05 for the homogeneity of the variances. This hypothesis has been taken into consideration in the $t$ test and one-way variance analyses.

Table 6 : The Test Results of the Differentness of Knowledge Sharing Types According to Demographical Features

\begin{tabular}{|l|c|c|c|c|c|}
\hline $\begin{array}{l}\text { Knowledge Sharing } \\
\text { Types }\end{array}$ & Gender & Age & Education & Work Time & Job \\
\hline $\begin{array}{l}\text { Explicit Knowledge } \\
\text { Sharing }\end{array}$ & $0.037^{*}$ & 0.163 & 0.202 & 0.320 & 0.502 \\
\hline $\begin{array}{l}\text { Tacit Knowledge } \\
\text { Sharing }\end{array}$ & 0.080 & $0.001^{*}$ & 0.840 & 0.201 & $0.043^{*}$ \\
\hline
\end{tabular}

According to the results of the tests that were applied, the value averages of explicit knowledge sharing of women and men show difference from each other (p:0.037). For explicit knowledge sharing, in terms of demographical variables, only in the gender variable a difference has been observed. As the result of one-way variance analysis which was applied for tacit knowledge sharing, significant differences are observed between the age groups (p:0.001) and the job groups (p:0.043).

Table 7: Scheffe Test Results of Tacit Knowledge Sharing According to Age

\begin{tabular}{|l|l|c|c|c|}
\hline \multirow{5}{*}{ Tacit Knowledge Sharing } & Age & $\mathbf{1 8 - 2 5}$ & $\mathbf{2 6 - 3 5}$ & $\mathbf{3 6 - 4 5}$ \\
\cline { 2 - 5 } & $\mathbf{2 6 - 3 5}$ & 0.022 & - & 0.024 \\
\cline { 2 - 5 } & $\mathbf{3 6 - 4 5}$ & - & 0.024 & - \\
\cline { 2 - 5 } & $\mathbf{4 6}$ and above & 0.025 & - & 0.019 \\
\hline
\end{tabular}

In table 7 , according to the results of scheffe test which has been used to test the differences between groups, differences have been observed between the age groups 18-25 year-olds and 26-35year-olds(p:0.022), between 26-35 year-olds and 36-45 year-olds (p:0.024), between 18-25 year-olds and 46 year-olds and above (p:0.025) and between $36-45$ year-olds and 46 year-olds and above (p:0.019). As the result of one-way variance analysis, in tacit knowledge sharing dimension significant differences have been observed between the groups according to job (p:0.043). 
Table 8: Scheffe Test Results of Tacit Knowledge Sharing According to Job

\begin{tabular}{|c|l|c|}
\hline \multirow{4}{*}{ Tacit Knowledge Sharing } & Job & $\begin{array}{l}\text { A s s is t a n t } \\
\text { Manager }\end{array}$ \\
\cline { 2 - 3 } & Worker & 0.030 \\
\cline { 2 - 3 } & Officer & 0.025 \\
\hline
\end{tabular}

In table 8, differences are observed between workers and assistant managers ( $p ; 0.030)$ and between officers and assistant managers (p:0.025) according to Scheffe test results. In terms of demographical variables, a difference is observed between the variables age and job for tacit knowledge sharing. Knowledge sharing types according to demographical variables show difference and the hypothesis is accepted.

\subsection{Difference Analyses of Knowledge Sharing Dimensions According to Demographical Features}

The differences of knowledge sharing dimensions according to demographical features have been analyzed.

Table 9 : The Test Results of the Differentness of Knowledge Sharing Dimensions According to Demographical Features

\begin{tabular}{|l|c|c|c|c|c|}
\hline $\begin{array}{l}\text { Knowledge Sharing } \\
\text { Dimensions }\end{array}$ & Gender & Age & Education & $\begin{array}{l}\text { Work } \\
\text { Time }\end{array}$ & Job \\
\hline Reward & 0.502 & 0.172 & 0.254 & $0.002^{*}$ & $0.000^{*}$ \\
\hline Being Mutual & $0.008^{*}$ & 0.311 & 0.838 & 0.145 & 0.149 \\
\hline Self-Efficacy & 0.801 & 0.347 & 0.069 & $0.016^{*}$ & 0.306 \\
\hline $\begin{array}{l}\text { Liking to Help the } \\
\text { Others }\end{array}$ & 0.608 & 0.309 & 0.393 & 0.062 & $0.010^{*}$ \\
\hline Respectability & 0.774 & 0.339 & 0.130 & 0.313 & 0.110 \\
\hline
\end{tabular}

In table 9, in terms of demographical features, dimension according to work time state (p:0.002). a difference in work time and job variables is As the result of one-way variance analysis that observed for reward dimension. As the result of has been applied for reward dimension, signione-way variance analysis that has been applied ficant differences have been observed between for reward dimension, significant differences the groups in reward dimension according to job have been observed between the groups in reward state (p:0.000).

Table 10: Scheffe Test Results of Reward Dimension According to Work Time

\begin{tabular}{|l|l|c|c|c|c|}
\hline \multirow{4}{*}{ Reward } & Work Time & $\mathbf{1 - 5}$ years & 6-10 years & $\begin{array}{l}\mathbf{1} \text { 1 - 1 5 } \\
\text { years }\end{array}$ & $\begin{array}{l}\mathbf{1 6} \text { years and } \\
\text { more }\end{array}$ \\
\cline { 2 - 6 } & $\begin{array}{l}\text { Less than 1 } \\
\text { year }\end{array}$ & 0.013 & - & 0.005 & - \\
\cline { 2 - 6 } & $\mathbf{1 1 - 1 5}$ years & - & 0.022 & - & 0.010 \\
\hline
\end{tabular}

In table 10, as the result of scheffe test, differences worked for less than 1 year and for 11-15 years have been observed between the staff who have (p:0.005), between for less than 1 year and for 
Table 11: Scheffe Test Results of Reward Dimension According to Job

\begin{tabular}{|l|l|c|c|c|}
\hline \multirow{2}{*}{ Reward } & Job & Officer & Assistant Manager & Manager \\
\cline { 2 - 5 } & Worker & 0.000 & 0.011 & 0.023 \\
\hline
\end{tabular}

In table 11, according to Scheffe test results, of independent sample $t$ test that was applied differences have been observed between workers for the dimension of being mutual, significant and officers ( $p: 0.000)$, between workers and as- differences have been observed between women sistant managers (p:0.011) and between workers and managers(p:0.023).

For the dimension of being mutual, only in gender variable, a difference have been observed in terms of demographical variables. As the result employees and men employees. The value averages of being mutual dimension for women and men employees are not equal. When knowledge is shared women's expectation of something in return is higher (p:0.008).

\section{Table 12: Scheffe Test Results of Self-Efficacy Dimension According to Work Time}

\begin{tabular}{|l|l|c|}
\hline \multirow{2}{*}{ Self-efficacy } & Work Time & $\mathbf{1 1 - 1 5}$ years \\
\cline { 2 - 3 } & Less than 1 year & 0.037 \\
\hline
\end{tabular}

In Table 12, in terms of demographical features, only according to work time, differences between the groups are observed for self-efficacy dimension. As the results of one-way variance analysis, in self-efficacy dimension, significant differences have been observed between the groups according to work time (p:0.016). A difference has been observed between the staff who have worked for less than 1 year and who have worked for 11-15 years (p:0.037).

Table 13: Scheffe Test Results of Liking to Help the Others Dimension According to Job

\begin{tabular}{|l|l|c|c|}
\hline Liking to Help & Job & Worker & Officer \\
\cline { 2 - 4 } the Others & Assistant Manager & 0.003 & 0.011 \\
\hline
\end{tabular}

As the results of one-way variance analysis for liking to help the others dimension, significant differences have been observed between the groups (p:0.010). According to scheffe test result in table 13, differences have been observed between workers and assistant managers (p:0.003) and between officers and assistant managers (p:0.011). In respectability dimension, A difference has not been observed in any variable in terms of demographical variables.
Knowledge sharing dimensions according to demographical variables show difference and the hypothesis is accepted.

\subsection{Difference Analyses of Knowledge Sharing Types According to Organizational Culture Types}

The difference analyses of explicit and tacit knowledge sharing according to organizational culture types are as follows. 
Table 14: The Test Results of Differences of Knowledge Sharing Types According to Organizational Culture Types

\begin{tabular}{|l|c|c|}
\hline $\begin{array}{c}\text { Organizational Culture } \\
\text { Types }\end{array}$ & $\begin{array}{c}\text { Explicit } \\
\text { Knowledge } \\
\text { Sharing }\end{array}$ & $\begin{array}{c}\text { Tacit } \\
\text { Knowledge } \\
\text { Sharing }\end{array}$ \\
\cline { 1 - 1 } Clan & \multirow{2}{*}{$0.006^{*}$} & \multirow{2}{*}{$0.017^{*}$} \\
\cline { 1 - 1 } Adhocracy & & \\
\hline Mierarchy & & \\
\hline
\end{tabular}

As the result of one-way variance analysis that has been carried out to determine whether explicit knowledge sharing levels change according to organizational culture groups or not, it has been concluded that organizational culture type is an effective factor $(\mathrm{F}=4.205, \mathrm{p}: 0.006)$. As the result of one-way variance analysis that has been carried out to determine whether tacit knowledge sharing levels change according to organizational culture groups or not, it has been concluded that organizational culture type is also an effective factor $(\mathrm{F}=6.559, \mathrm{p}: 0.017)$.

\section{Table 15: Scheffe Test Results of Knowledge Sharing Types According to} Organizational Culture Types

\begin{tabular}{|c|c|c|c|c|}
\hline $\begin{array}{c}\text { Explicit } \\
\text { Knowledge } \\
\text { Sharing }\end{array}$ & $\begin{array}{c}\text { Organizational } \\
\text { Culture }\end{array}$ & Adhocracy & Clan & Market \\
\cline { 2 - 5 } & Market & 0.006 & - & - \\
\hline $\begin{array}{c}\text { Tacit Knowledge } \\
\text { Sharing }\end{array}$ & Clan & & - & 0.029 \\
\cline { 2 - 5 } & Adhocracy & - & - & 0.002 \\
\hline
\end{tabular}

In table 15 , in order to determine which group shows difference, scheffe test results, from post hoc tests, can be observed. According to this, explicit knowledge sharing levels of organizations that have adhocracy and market organizational culture type are significantly different from each other (p:0.006). According to the results of tacit knowledge sharing levels according to organizational cultur groups, tacit knowledge sharing of clan and market cultures $(\mathrm{p}=0.029$ and adhocracy and market cultures $(\mathrm{p}=0.002)$ are significantly different from each other. According to the results of one-way variancew analysis, organizational culture types show difference according to tacit knowledge sharing.
Knowledge sharing types according to organizational culture types show difference and the hypothesis is accepted.

\subsection{Difference Analyses of Knowledge Sha- ring Dimensions According to Organizational Culture Types}

The differences have been shown as the result of one-way variance analysis that has been carried out to determine whether knowledge sharing dimensions change according to organizational culture groups or not. 
Table 16: The Test Results of Differences of Knowledge Sharing Dimensions According to Organizational Culture Types

\begin{tabular}{|c|c|c|c|c|c|}
\hline $\begin{array}{l}\text { Organizational } \\
\text { Culture Types }\end{array}$ & Reward & $\begin{array}{l}\text { Being } \\
\text { Mutual }\end{array}$ & Self-efficacy & $\begin{array}{l}\text { Liking to Help the } \\
\text { Others }\end{array}$ & Respectability \\
\hline Clan & \multirow{4}{*}{0.003} & \multirow{4}{*}{0.011} & \multirow{4}{*}{0.016} & \multirow{4}{*}{0.026} & \multirow{4}{*}{0.017} \\
\hline Adhocracy & & & & & \\
\hline Hierarchy & & & & & \\
\hline Market & & & & & \\
\hline
\end{tabular}

In table 16 , in every dimension, differences have been determined according to the result of oneway variance analysis that has been carried out to determine whether knowledge sharing dimensions show difference according to organizational culture groups or not.

Table 17: Scheffe Test Results of Knowledge Sharing Dimensions According to Organizational Culture Types

\begin{tabular}{|c|c|c|c|}
\hline $\begin{array}{l}\text { Knowledge Sharing } \\
\text { Dimensions }\end{array}$ & Organizational Culture & Clan & Adhocracy \\
\hline \multirow{3}{*}{ Reward } & Adhocracy & - & - \\
\hline & Hierarchy & - & 0.002 \\
\hline & Market & 0.007 & 0.005 \\
\hline \multirow{3}{*}{ Being Mutual } & Adhocracy & 0.001 & - \\
\hline & Hierarchy & - & 0.002 \\
\hline & Market & - & 0.008 \\
\hline \multirow{3}{*}{ Self-Efficacy } & Adhocracy & - & - \\
\hline & Hierarchy & - & 0.031 \\
\hline & Market & - & 0.001 \\
\hline \multirow{3}{*}{$\begin{array}{l}\text { Liking to Help the } \\
\text { Others }\end{array}$} & Adhocracy & 0.004 & - \\
\hline & Hierarchy & - & 0.010 \\
\hline & Market & - & 0.012 \\
\hline \multirow{3}{*}{ Respectability } & Adhocracy & 0.008 & - \\
\hline & Hierarchy & - & 0.001 \\
\hline & Market & 0.013 & 0.009 \\
\hline
\end{tabular}

In table 17, according to the scheffe test results, in terms of reward dimension, hierrachy and adhocracy cultures (p:0.002), market and clan cultures (p:0.007) and market and adhocracy cultures (p:0.005) are different from each other. In terms of being mutual dimension, adhocracy and clan cultures (p:0.001), hierarchy and adhoc- racy cultures (p:0.002) and market and adhocracy cultures (p:0.008) are different from each other. In terms of self-efficacy dimension, hierrachy and adhocracy cultures (p:0.0031) and market and adhocracy cultures (p:0.001) are different from each other. In terms of helping the others dimension, adhocracy and clan cultures (p:0.004), hierarchy 
and adhocracy cultures (p:0.010) and market and adhocracy cultures (p:0.012) are different from each other. In terms of respectability dimension, adhocracy and clan cultures (p:0.008), hierarchy and adhocracy cultures (p:0.001) and market and clan cultures (p:0.013) and market and adhocracy cultures (p:0.009) are different from each other.

Knowledge sharing dimensions according to organizational culture types show difference and the hypothesis is accepted.

\section{Conclusion}

The idea that the competition level will increase when knowledge is shared has raised the interest in knowledge sharing recently. Therefore, managers try to lessen the effects of the factors that block knowledge sharing in the organizations. There are individual, organizational and technological factors that influence the staff's knowledge sharing. However, the most important factor that blocks knowledge sharing in the organization is considered to be organizational culture. Even if information technologies are regarded as the most important element for the success of knowledge management and knowledge sharing concepts, the existence of a suitable organizational culture is much more important. Organizational culture which is formed with the founder's influence, with surrounding factors and with the influence of the organization members shapes the knowledge sharing. Especially revealing the knowledge kept in the minds of the staff and enabling this knowledge to be shared is considered to have a strategic importance. There must be a suitable organizational culture in which the staff can share their tacit knowledge that they gained from their experiences. In the scope of the research factor and reliability analyses have been applied for the validity and reliability of the scale. $T$ test and anova analyses have been used to test the hypotheses of the research. Prevailing organizational cultures in the organizations have been determined at the end of the research. According to this, it is concluded that in most of the organizations, market culture is the prevailing organizational culture. Market culture is a culture of rivalry. Having tacit knowledge is regarded as a means of rivalry. Besides, tacit knowledge sharing average in most organizations is higher compared to other dimensions. In most of the organizations, liking to help the others dimension has a higher average value. It is concluded that the staff share knowledge due to the fact that they like to help the others in every culture type, while they are sharing knowledge. The culture in which explicit and tacit knowledge sharing is most important is the market culture. The most suitable culture for rewarding is the hierarchy culture, the culture in which being mutual is the most important is the clan culture, the culture in which self-efficacy is the most important is hierarchy, the culture in which liking to help the others is the most important is market culture and the culture in which knowledge sharing is regarded as respectability is the market culture. When the findings that have been obtained are examined whether the participants' demographical features show difference in terms of explicit knowledge sharing dimension, no difference has been observed according to age, education, work time and job. Explicit knowledge sharing show difference according to gender. In tacit knowledge sharingg dimension, no difference has been observed according to demographical factors in terms of gender, education, work time. Differences have been observed between the 
groups of 18-25 year-olds and 26-35 year-olds, between 26-35 year-olds and 36-45 year-olds, between 18-25 year-olds and 46 year-olds and above and between $36-45$ year-olds and 46 yearolds and above.

In tacit knowledge sharing dimension according to job, it is concluded that workers and officers attach less importance to tacit knowledge sharing than assistant managers. The reward dimension perspectives of the staff whose work time is between 11-15 years and who work as officers show difference according to the other staff with different titles. From women's point of view in knowledge sharing, mutuality of knowledge sharing has been considered more important by women than men. In self-efficacy dimension, only the the staff who has worked for 11-15 years are different from the other groups. In liking to help the others dimension, workers and officers' perspectives show difference from senior officials. When the state of knowledge types and knowledge sharing in terms of organizational cultures are examined, differences have been observed. It has been cocluded that in explicit and tacit knowledge sharing adhocracy and market cultures show difference and in tacit knowledge sharing clan and market cultures show difference. In most of the knowledge sharing dimensions it has been observed that adhocracy and hierarchy cultures and adhocracy and market cultures show differences from each others. In accordance with this research, it has been confirmed that, as in the literature tacit knowledge sharing is important. It is thought that rewarding system will be useful to encourage tacit knowledge sharing. Consequently a suitable organizational culture is important to encourage knowledge sharing in organizations. An inappropriate organizational culture can have preventive effects on knowledge sharing. This research, which has been carried out to define the relationship between organizational culture and knowledge sharing, can be a guiding research for those who think of conducting a research on the same subject. Due to the fact that the study is limited to manufacturing sector, similar studies can be carried out in different sectors, as well. Besides, different studies can be done with different organizational culture models instead of this research's base model, which is the Competing Values model of organizational culture. Apart from organizational culture, other factors which influence knowledge sharing can also be searched.

\section{REFERENCES}

$A K G \ddot{U} N, A ., \&$ KESKINN, H., \& GÜUSEL, A., (2009). Bilgi Yönetimi ve Öğrenen Örgütler, Eflatun Yayınevi, Ankara

ALAVI, M., \& LEIDNER, D., (2001). Review Knowledge Management and Knowledge Management Systems: Conceptual Foundations and Research Issues, MIS Quarterly, 25(1), 107-136

ALTUNIŞIK, R., (2007). Sosyal Bilimlerde Araştırma Yöntemleri, Sakarya Yayıncılık, Sakarya

BARTOL, K.M., (2002). Encouraging Knowledge Sharing: The Role Of Organizational Reward Systems, Journal of Leadership\&Organizational Studies, 9, 64-77

BARUTÇUGIL, İ., (2002). Bilgi Yönetimi, Kariyer Yayınc1lı, İstanbul 
BAYRAM, H., (2010). Bilgi Toplumu ve Bilgi Yönetimi, 1.Baskı, Etap Yayınevi, İstanbul

BEIJERSE, R.P., (2000). Knowledge Management in Small and Medium- Sized Companies: Knowledge Management for Entrepreneurs, Journal Of Knowledge Management, 4(2), $162-179$

CAMERON, K., (2006). Diagnosic and Changing Organizational Culture, Jossey Bass A Wiley Imprint

CELEP, C., (2003). Bilgi Yönetimi Örgütlerde Bilgi Paylaşma Kültürü Yaratma, Anı Yayıncılık, Ankara

DAVENPORT, T., (2000). İş Dünyasında Bilgi Yönetimi, (Çev: Günhan Günay), Rota Yayıncılık, İstanbul

DEMIREL, Y., (2007). Müşteri İlişkileri Yönetimi ve Bilgi Paylaşımı, IQ Kültür-Sanat Yayıncılık, 2.Bask1, İstanbul

DINÇMEN, M., (2010). Bilgi Yönetimi Ve Uygulamaları, Papatya Yayıncılık, 1.Baskı, İstanbul

$D O \breve{G} A N, B$. , (2007). Örgüt Kültürü, Beta Basım Yayıncılık, 1.Bask1, İstanbul

DURNA, U., \& Demirel, Y., (2008). Bilgi Yönetiminde Bilgiyi Anlamak, Erciyes Üniversitesi İktisadi ve İdari Bilimler Fakültesi Dergisi, $30,130-156$

ERDEM,R., (2007). Örgüt Kültürü Tipleri İle Örgütsel Bağlılık Arasındaki İlişki: Elazı̆̆ İl Merkezindeki Hastaneler Üzerinde Bir Çalışma, http//www.arastirmax.com/system/ files/dergiler/14926/makaleler/2/2/arastirmaxorgut-kulturu-tipleri-ile-orgutsel-baglilik-arasi ndaki-iliski-elazig-il-merkezindeki-hastane ler-uzerinde-bir-calisma.pdf, (Access Date: 02.02.2013)

ERDEM, R., \& ADIGÜZEL O.,\& KAYA A., (2010). Akademik Personelin Kurumlarına İlişkin Algıladıkları ve Tercih Ettikleri Örgüt Kültürü Tipleri, Erciyes Üniversitesi İktisadi ve İdari Bilimler Fakültesi Dergisi, 36, 73-88

ERDIL, O. ,\& KITAPÇI, H., (2009). Bilgi Yönetiminin İşletme Etkinliği İle İlişkisi: Ampirik Bir Araştırma, Gebze İleri Teknoloji Enstitüsü İktisadi İdari Bilimler Dergisi, 23, 113-128

EREN, E., (2010). Örgütsel Davranış ve Yönetim Psikolojisi, 12. Baskı, Beta Basım Yayım, İstanbul

ERKMEN, T., (2010). Örgüt Kültürü, Beta Basım Yayımcılık, 1.Baskı, İstanbul

GOODMAN, E., (2001). The Competing Values Framework: Unders Standing The Impact Of Organizational Culture On The Quality Of Work Life, Organizational Development Journal, 19(3), 58-68

GURTEEN, D., (1999). Creating A Knowledge Sharing Culture, Knowledge Management Magazine, 2(5), 328-339

HOFSTEDE, G., (1990). Measuring Organizational Cultures: A Qualitative and Quantitative Study Across Twenty Cases, Administrative Science Quarterly, 35(2), 286-316.

HOOIJBERG, R., (1993). On cultural change: Using the competing values framework to help leaders execute a transformational strategy, Human Resource Management, 32, 29-50 
HUNG, Y., \&CHUANG, Y., (2006). Factors Affecting Knowledge Sharing: A Content Analysis Of Empirical Finding, http://www. myacme.org/ACMEProceedings09/p19.pdf, 22-45, (Access Date: 21.04.2013)

IPE, M., (2003). Knowledge Sharing In Organizations: A Conceptual Framework, Human Resource Development Review, 2, 337-359

KALKAN, V., \& KESKİN, H., (2005). KOBI'lerde Bilgi Yönetimi Süreci ve Araçları: Literatür Değerlendirmesi ve Bir Araştırma, Ahmet Yesevi Üniversitesi, 35, 173-206

KANKANHALLI, A.,\& TAN, B.,\& WEI, K., (2005). Contributing Knowledge to Electronic Knowledge Reprositories: An Empirical Investigation, MIS Quarterly, 29, 113-143, 2005

KARADAL, H., \&ÖZÇINAR F., (2003). Örgüt İçin Bilgi Paylaşımı: Bir Örnek Olay Çalışması, II. Ulusal Bilgi, Ekonomi ve Yönetim Kongresi Bildiriler Kitab1, Kocaeli, 17-18 Mayıs 2003

KURT, M., (2005). İşletmelerde Bilginin Rolündeki Değişim ve Bilgi Yönetimi, C. C. Aktan ve İ. Y. Vural (Ed.) Bilgi çă̆l, bilgi yönetimi ve bilgi sistemleri içinde, 249-265, Çizgi Kitabevi, Konya

LEE, J.M., (2001). The Impact Of Knowledge Sharing, Organizational Capability and Partnership Quality on IS Outsourcing Success, Information \& Management, 38, 323-335

LONG D.,\&David W.\&FAHEY, L., (2000). Diagnosing Cultural Barriers To Knowledge Management, Academy Of Management Executive,14(4), 113-127
MATZLER , K., (2007). Personality Traits and Knowledge Sharing, Journal of Economic Psychology, 29, 301-313

MURAT, G.,\& AÇIKGÖZ, B., (2007). Yöneticilerin Örgüt Kültürü Algılamalarına İlişkin Bir Analiz: Zonguldak Karaelmas Üniversitesi Örneği, ZKÜ Sosyal Bilimler Dergisi, 3(5),1-20

ODABAŞ, H., (2005). Bilgi yönetimi sistemi, C. C. Aktan ve İ Y. Vural (Ed.). Bilgi çağı, bilgi yönetimi ve bilgi sistemleri içinde, ss. 101-120, Çizgi Kitabevi, Konya

RUPPEL C.P., \& H.S.J., (2001). Sharing Knowledge Through Intranets: A Study of Organizatinal Culture and Intranet Implemantation, IEEE Transactions on Professinal Communication, 44(1), 37-52

SIPAHI,B., (2010).Sosyal Bilimlerde SPSS'le Veri Analizi, Beta Basım Yayım Dağıtım, 3.Bask1, İstanbul

SUPPIAH,V., \& SANDHU, M., (2011). Organisational Culture's Influence On Tacit Knowledge-Sharing Behaviour, Journal Of Knowledge Management, 15(3), 462-477

STEWART, T., (1997). Entelektüel Sermaye: Kuruluşların Yeni Zenginliği, BZD Yayınları, İstanbul

SZULANSKI G., (2000). Colaborative Climate and Effectiveness of Knowledge Work, Journal Of Knowledge Management, 6(5), 420-433

ŞIŞMAN, M., (2007). Örgütler ve Kültürler, Pegem Yayıncılık, Ankara 
TIWANA, A., (2003). Bilginin Yönetimi, (Çeviren: Elif Özsayar), Dışbank Kitapları,1.Baskı, İstanbul, 2003

UZUN, D., (2007). Örgüt Kültürünün Bilgi Yönetim Sürecine ve Örgütsel Performansa Etkisi: Beş Yıldızlı Otel İşletmelerinde Bir Uygulama, (Dokuz Eylül Üniversitesi, Sosyal Bilimler Enstitüsü, Turizm İşletmeciliği Anabilim Dal, Basılmamış Doktora Tezi), İzmir

YAĞGURLU, A., (2006). Örgüt Kültürü: Tanımlar ve Yaklaşımlar, http://www.todaie.gov.tr/dosya/ orgutkulturu.pdf, (Access Date: 12.05.2013)

YENIÇERI, Ö., (2007). İşletme Koşullarının Örgüt İçi Bilgi Paylaşım İklimine Etkisi, M.Ü. Sosyal Bilimler Enst. Dergisi, 27, 9-21
YENIÇERI, Ö., \&DEMIREL,Y., (2007). Örgüt İçi Bilgi Paylaşımına Yönelik Bireysel ve Örgütsel Engeller Üzerine Bir Araştırma, Selçuk İ.İ.B.F Dergisi, 12, 221-234

YENIÇERI, Ö., \& INCE,M., (2005). Bilgi Yönetim Stratejileri ve Girişimcilik, IQ Kültür-Sanat Yayınc1l1k, 1.Bask1, İstanbul

ZAIM, H., (2005). Bilginin Artan Önemi ve Bilgi Yönetimi, İşaret Yayınları, 1.Baskı, İstanbul

ZHANG,X., (2011).Cultural Influences On Explicit and Implicit Knowledge Sharing Behaviour In Virtual Team, International Journal of Computer Science \&Information Technology, 3, 29-44 


\section{ÖRGÜT KÜLTÜRÜ VE BILGİ PAYLAŞIMI ILIŞKISİ: KIRKLARELİ IMMALAT SEKTÖRÜ ÖRNEĞİ}

Özet: Bilgi, günümüzde işletmeler için çok önemli bir kaynaktır. Bilgi işletmeleri ayakta tutmanın yanı sıra tüm ürün ve hizmetlerin önemli bir parçası haline gelmiştir. Bilginin işletmeye yarar sağlaması için bilgi yönetimi süreçlerinden geçmesi gereklidir. Bilgi yönetimi süreçlerinden bilgi paylaşımı, örgüte başarı katmaktadır. Kültür, toplumlarda olduğu gibi örgütlerde de davranışları etkilemesi bakımından büyük öneme sahiptir. Örgüt kültürü bilgi paylaşımının başarısını etkileyen önemli bir faktör olarak görülmektedir. $\mathrm{Bu}$ çalışma ile amaçlanan işletmelerde hakim olan örgüt kültürünü tespit etmek, örgüt kültürü türleri ile bilgi paylaşımı arasındaki farklılıkları ortaya koymaktır. Çalışmada öncelikle örgüt kültürü ve türleri, bilgi, bilgi türleri, bilgi yönetimi ve bilgi paylaşımı incelenmiş, uygulama bölümünde anket yöntemi ile veriler elde edilmiş̧ir. Araştırmanın evrenini Kırklareli Merkez İlçede faaliyet gösteren, 50'den fazla çalışanı bulunan imalat işletmeleri oluşturmaktadır. Sosyal Güvenlik Kurumu 2012 yılı kayıtlarına göre Kırklareli Merkez İlçede 17 imalat işletmesi bulunmakta ve araştırmanın evreni 3006 çalışandan oluşmaktadır. Araştırmaya konu olan işletmeler tekstil, gıda, makine, alüminyum imalat, döküm sektörlerinde faaliyet göstermektedir. Araştırmada tabakalı örnekleme yöntemi kullanılmıştır Kırklareli merkez ilçede bulunan 17 işletmeden, 12 işletme çalışmaya katılmayı kabul etmiş̧ir. Ulaşılan 12 işletmenin her birinin çalışan sayısının \%15'ine anket teslim edilmiştir ve 378 anket elde edilmiştir. Anket formu; örgüt kültürü, bilgi paylaşımı türü ve bilgi paylaşımı boyutları olmak üzere üç ölçek ve demografik sorulardan oluşmaktadır. Anket forumunda kullanılan ölçekler 5'li likert tipi ölçeklerdir. Anket formunda demografik bilgilere ilişkin 5 soru, örgüt külttürü türleri ile ilgili 16 soru, bilgi paylaşımı türlerine ilişkin 7 soru, bilgi paylaşımı boyutlarına ilişkin 21 soru bulunmaktadır. Bu çalışmada örgüt kültürü Cameron ve Quinn'in, "Rekabetçi Değerler Yaklaşımı" modelinde ele alınan klan, adhokrasi, hiyerarşi ve pazar kültürü kullanılmıştır. Bilgi paylaşımına yönelik olarak Xi Zhang'ın, "Kültürün Açık ve Örtülü Bilgi Paylaşımı Davranışı Üzerine Etkisi” konulu çalışmasında kullandığı model esas alınmıştır. Bilgi paylaşımı boyutlarına ilişkin sorular ile açık ve örtülü bilgi paylaşımına yönelik sorular Kankanhalli'den uyarlanmıştır. Bilgi paylaşımı; bilgi paylaşımı türü ve bilgi paylaşımı boyutları olarak incelenmiştir. Bilgi paylaşımı türü örtülü ve açık bilgi olarak, bilgi paylaşımı boyutları ise ödül, karşılıklı olma, öz yeterlilik, başkalarına yardım etmekten hoşlanma ve saygınlık olarak ele alınmıştır. Verilerin değerlendirilmesinde SPSS 17.0 programı kullanılmıştır. Araştırmada kullanılan ölçeklere ilişkin güvenilirlik analizi ve ölçeklerin yapısal geçerliliği için faktör analizi uygulanmıştır. Öncelikli olarak araştırmaya katılan çalışanların demografik özelliklerine yer verilmiştir. Verilerin analizinde frekans tabloları, ortalama değerleri, bağımsız grupların karşılaştııılması için $t$ test, ikiden fazla grupların karşılaştırılması için varyans analizi(anova) uygulanmıştır. Araştırmaya katılanların cinsiyet dağılımı incelendiğinde \%48.7'si kadın, \%51.3’ü erkek olduğu görülmektedir. Ankete katılanların yaş dağılımı incelendiğinde $\% 22.8$ 'i 18-25 yaş, \%47.4'ü 26-35 yaş, \%25.9'u 36-45 yaş, \% 4.0'1 46 yaş ve üzerinde yer almaktadır. Ankete katılanların \%11. 1'i ilkokul, \%32.8'i ortaokul, \%39.9'u lise, \%9.0'u ön lisans, \%7.1'i lisans ve üstü mezunudur. Ankete katılanların çalışma süresi açısından dağılımı incelendiğinde \%40.7'si 1 yıldan daha az, \%47.4'ü 1-5 yıl, \%8.2'si 6-10 yıl, \%1.1'i 11-15 y1l, \%2.6's1 16 yıl ve üzerinde sürelerde çalışmaktadır. Ankete katılanların görevleri açısından dağılım incelendiğinde \%69.6'sı iş̧̧i, \%17.7'si memur, \%8.2'si şef-ustabaşı, \%2.4'ü mühendis, \%0.8'i müdür yardımcıs1, \%1.3'ü müdür olarak çalışmaktadır. Araştırma sonucunda işletmelerde hakim olan örgüt kültürleri belirlenmiştir. Buna göre bir çok işletmede pazar kültürünün hakim olduğu sonucu ortaya çıkmıştır. Bunun yanı sıra birçok işletmede örtülü bilgi paylaşımı ortalaması diğer boyutlara göre daha yüksektir. İşletmelerin büyük çoğunluğunda başkalarına yardım etmekten hoşlanma boyutu daha yüksek ortalama değere sahiptir. Açık 
ve örtülü bilgi paylaşımının en önemli olduğu kültür pazar kültürüdür. Ödüllendirmeye en uygun kültür hiyerarşi kültürü, karşılık almanın en önemli olduğu kültür klan, öz yeterliliğin en önemli olduğu kültür hiyerarşi, başkalarına yardım etmekten hoşlanmanın en önemli olduğu kültür pazar, bilgi paylaşımının saygınlık olarak görüldüğü kültür ise pazar kültürüdür. Araştırma sonuçlarına göre bilgi paylaşımı türleri ve boyutları demografik özelliklere ve kültür türlerine farkl11ık göstermektedir.

Anahtar Kelimeler: Bilgi, Bilgi Paylaşımı, Örgüt Kültürü 